\title{
ДЕЯТЕЛЬНОСТЬ ПОГРАНИЧНЫХ ОРГАНОВ ФЕДЕРАЛЬНОЙ СЛУЖБЫ БЕЗОПАСНОСТИ РОССИЙСКОЙ ФЕДЕРАЦИИ В ОБЛАСТИ ЗАЩИТЫ ГРАНИЦ ИНОСТРАННЫХ ГОСУДАРСТВ
}

Аннотачия. Предметом статьи является осуществление деятельности пограничньх органов Федеральной службы безопасности Российской Федерации в области защиты государственных границ иностранных стран. Автором подробно проводится теоретико-правовой анализ правового регулирования деятельности пограничных подразделений и должностных лиц Федеральной службы безопасности Российской Федерации с позиции административно-правового регулирования. Рассматриваются авторские позиции относительно проблематики выполнения сотрудниками пограничных подразделений Федеральной службы безопасности Российской Федерации в иностранных государствах полномочий в сфере защиты государственных грании, поскольку регулируется эта деятельность национальным законодательством этих государств. Автором обращается внимание также на то, что значительная часть полномочий российских пограничников вообще не урегулирована ни национальным законодательством, ни международными договорами. Методологическую основу статьи составили теоретический, общефилософские методы (диалектика, системный метод, анализ, синтез, наблюдение, моделирование), а также правовые методы (формально-логический). Основные выводы, которые сделаны по итогам исследования, состоят в том, что на постсоветском пространстве сложилась разнородная ситуация в сфере охраны Государственных границ Российской Федерации; приоритет в защите государственных границ бывшего СССР отводился именно внешним границам стран СНГ, за исключением прибалтийских стран, которые начали в первую очередь оборудовать государственную границу с Российской Федерацией; именно необходимостью защиты внешних границ стран СНГ, а также невозможностью выполнения этой функции самостоятельно в 90-е г2. ХХ века, объясняется присутствие в иностранных государствах российских пограничных войск. Основным вкладом, который сделан автором в настоящей статье это проведенный глубокий анализ деятельности пограничных подразделений и должностных лиц Федеральной службы безопасности Российской Федерации в области защиты границ иностранных государств. Новизна статьи заключается в обосновании возможности действия российского, в том числе административного законодательства за пределами Российской Федерации, определении особенностей организации и осуществления деятельности пограничными органами Федеральной службы безопасности Российской Федерации в области защиты границ иностранных государств, поскольку на постсоветском пространстве сложилась разнородная ситуация в сфере охраны Государственных границ Российской Федерации и приоритет в защите государственных границ бывшего СССР отводился именно внешним границам стран СНГ, за исключением прибалтийских стран.

Ключевые слова: пограничные органы, оперативная группа, государственная граница, договор, государство, военская часть, комендатура, сухопутное направление, безопасность, полномочия.

Abstract. The research subject is the activity of border authorities of the Federal Security Service of the Russian Federation in protection of the borders of foreign states. The author analyzes legal regulation of the activities of border authorities and officials of the Federal Security Service of the Russian Federation from the position of administrativelegal regulation. The paper presents the author's positions on the authorities of the officials of the Federal Security Service's border agencies in foreign states in the sphere of state borders protection, as long as this activity is regulated by the national legislation of these states. The author pays attention to the fact that the significant part of authorities of Russian border guards is not regulated at all, either by the national legislation or by international treaties. The research methodology comprises theoretical and general philosophical methods (dialectics, the system method, analysis, synthesis, observation, and modeling), and legal methods (formal logical). The author concludes that on the post-Soviet space a heterogeneous situation had developed in the sphere of state borders protection; the former USSR's state borders protection priority was placed on the external borders of the CIS member-states apart from the Baltic states which started equipping the state border with the Russian Federation in the first instance. The need for the CIS's external borders protection and the impossibility to perform this function on their own in the 1990s explains the presence of Russian border troops in foreign states. The author of the study analyzes the activities of border authorities and officials of the Federal Security Service of the Russian Federation in protection of borders of foreign states. The author substantiates the possibility to apply Russian legislation, including the administrative one, beyond the borders of the Russian Federation; the author defines the peculiarities of organizing and performing their work 
by the border authorities of the Federal Security Service of the Russian Federation for the protection of foreign states' borders, as long as heterogeneous conditions had formed on the post-Soviet space.

Key words: state border, treaty, state, military unit, garrison headquarters, overland direction, security, authorities, operational group, border authorities.

$\mathrm{B}$ настоящее время пограничные органы Федеральной службы безопасности Российской Федерации выполняют свои полномочия не только на территории Российской Федерации, но и за её пределами, что связано с двусторонними договорами, заключёнными с этими государствами. К государствам, в которых действуют пограничные подразделения Федеральной службы безопасности Российской Федерации, относятся: Армения, Абхазия и Южная Осетия. Более того, в Таджикистане (российские пограничники осуществляли охрану границы Таджикистана с Афганистаном в 1992-2005 гг.; в 2005 г. все заставы и вся инфраструктура в Республике Таджикистан переданы национальным пограничным структурам Таджикистана, а от Российской Федерации действуют только советники, а также отдельные воинские части. С 1992 по 2005 гг. российские пограничники осуществляли процессуальную деятельность и составляли документы исключительно на основе законодательства Республики Таджикистан), Туркмении и Киргизии работают российские пограничные советники.

В соответствии с Договором между Российской Федерацией и Туркменистаном (подписан 23 декабря 1993 года в г. Ашхабад) «0 совместной охране государственной границы Туркменистана и статусе военнослужащих Пограничных войск Российской Федерации на территории Туркменистана», а также приказом главнокомандующего Пограничными войсками Российской Федерации сформирована Оперативная группа пограничных войск Российской Федерации в Туркменистане. Вместе с указанным договором были подписаны «Положение об объединённом командовании», «Положение об оперативной группе пограничных войск», «Протокол о порядке финансирования» и «Протокол о материально-техническом снабжении и жизнеобеспечении»). Стоит отметить, что договор в настоящее время продолжает действовать, но, по сути, ни он, ни принятые протоколы в полном объёме не выполняются.

В связи с созданием собственных пограничных войск в Республике Казахстан и организацией охраны кыргызско-китайского участка границы упразднён Восточный пограничный округ и 08.11.1992 г. Указом Президента Российской Федерации организована Группа пограничных войск России в Республике Кыргызстан. После вывода российских пограничников из Кыргызстана в 1999 году в стране осталась группа военных советников, личный со- став которых время от времени то уменьшался, то увеличивался. По состоянию на 6 марта 2016 года в Кыргызстане действует оперативная группа Пограничной службы Федеральной службы безопасности Российской Федерации в Кыргызстане, которую называют военными советниками.

Деятельность пограничных подразделений за пределами Российской Федерации имеет свою специфику и особенности. Так, например, в Армении в международном аэропорту «Звартноц Армения» паспортный контроль выезжающих и прибывших граждан вместе с пограничниками Национальной службы безопасности Армении осуществляют пограничники Федеральной службы безопасности Российской Федерации, а именно Пограничное управление Федеральной службы безопасности Российской Федерации в Республике Армении.

Пограничники Федеральной службы безопасности Российской Федерации несут службу в соответствии с подписанным 30 сентября 1992 года между Республикой Армения и Российской Федерацией договором «О статусе пограничных войск Российской Федерации, находящихся на территории Республики Армении и условиях их функционирования» [1], который в неизменном виде действует и в настоящее время.

Однако стоит отметить, что в договоре прямо не предусмотрено право несения службы пограничниками Российской Федерации в каком-либо аэропорту Армении, но по факту такая деятельность осуществляется. Так, в статье 3 договора определяется, что для осуществления исполнения задач, которые не связаны с охраной границы с Турцией и Ираном (исключение составляют работы по ликвидации аварий, стихийных бедствий, катастроф), не привлекаются пограничные войска Российской Федерации.

Более того, в статье 6 договора «0 статусе пограничных войск Российской Федерации, находящихся на территории Республики Армении и условиях их функционирования» указывается, что пограничными войсками России, согласно действующим законодательным актам, регламентирующим порядок пересечения границы, осуществляется пропуск лиц, транспортных средств, грузов, товаров и иных предметов через существующие пункты пропуска, которые располагаются на границе Республики Армения с Турцией и Ираном». В указанной статье речь идёт исключительно о пропускных пунктах на границе с Турцией и Ираном. 


\section{Административное и муниципальное право 5 (101) 2016}

В этой связи, требуется уточнение договора и указание в нём на то, что Национальная служба безопасности Республики Армения и Федеральная служба безопасности Российской Федерации совместно могут осуществлять контроль в аэропортах Республики Армения. В ином случае совместная их деятельность в международном аэропорту «Звартноц Армения» является законодательно не урегулированной, что может повлечь различные негативные правовые последствия.

В настоящее время Пограничное управление Федеральной службы безопасности Российской Федерации в Республике Армении включает в себя четыре пограничных отряда (в Гюмри, Армавире, Арташате и Мегри). Содержание российских пограничников в Армении общей численностью около 4,5 тыс. человек финансируется из бюджетов обоих государств. Российские пограничники осуществляют охрану границы Армении с Турцией и с Ираном.

Деятельность сотрудников пограничных подразделений Федеральной службы безопасности Российской Федерации в Республике Армения регулируется приказом Федеральной службы безопасности Российской Федерации «Об утверждении Положения о пограничном Управлении в Республике Армении».

По данному приказу составление протоколов об административных правонарушениях осуществляется российскими пограничниками по законодательству Республики Армения, однако хозяйственная деятельность, государственные закупки подразделений, регулируются законодательством Российской Федерации. Таможенный досмотр и контроль осуществляется таможенными органами Республики Армении. В настоящее время начинается передача отдельных участков государственной границы пограничникам Армении.

Еще одним государством, границу которого охраняют пограничные подразделения Федеральной службы безопасности Российской Федерации, является Республика Абхазия, а именно в этом государстве с 30 апреля 2009 года действует Пограничное управление Федеральной службы безопасности Российской Федерации в Республике Абхазия, которое функционирует на основании межгосударственного соглашения «0 совместных усилиях в охране государственной границы Республики Абхазия».

Указанное соглашение направлено на укрепление государственной границы Республики Абхазия с Грузией, а также гарантирует защиту суверенитета и независимости Республики Абхазия при участии Российской Федерации. В день подписания соглашения на территорию Республики Абхазии были введены подразделения пограничной служ- бы Федеральной службы безопасности Российской Федерации.

Помимо этого, того же 30 апреля 2009 года Россия подписала соглашение и с Южной Осетией о совместных усилиях в охране государственной границы. По этим соглашениям Абхазия и Южная Осетия «до формирования органов пограничной охраны в интересах обеспечения собственной безопасности и безопасности Российской Федерации делегируют российской стороне полномочия по охране государственной границы, морских пространств, на которые распространяются суверенитет, суверенные права и юрисдикция» указанных государств.

Соглашение с Абхазией предусматривало создание Управления пограничной службы Федеральной службы безопасности Российской Федерации в Республике Абхазия, формирование двух отделов (пограничных комендатур) (на сухопутном направлении - с местом дислокации в Гальском районе, на морском направлении - с местом дислокации в Гагрском районе) и до 20 пограничных застав (отделений), на которых будут совместно нести службу абхазские и российские пограничники. Парламент Абхазии ратифицировал «Соглашение между Российской Федерацией и Республикой Абхазия о совместных усилиях в охране государственной границы Республики Абхазия» 10 июля 2009 года.

2 мая 2009 года пресс-служба Регионального пограничного управления Федеральной службы безопасности Российской Федерации по Южному федеральному округу сообщила, что «пограничные подразделения успешно выполнили задачи по совершению марша и приступили к выполнению поставленных задач по охране границы в Абхазии и Южной Осетии».

В 2009-2010 гг. парламент Абхазии разрешил правительству Абхазии передать несколько гектаров земли в Гальском, Гудаутском и Гульрипшском районах республики в пользование Пограничного управления Федеральной службы безопасности Российской Федерации в Республике Абхазия: Пичора, Папынрхуа, Таглан, Хыпста (Гудаутский район), Дранда (Гульрипшский район).

Помимо пограничных подразделений Федеральной службы безопасности Российской Федерации в верхней части Кодорского ущелья, где проходит северо-восточная граница Абхазии с Грузией, на постоянной основе дислоцированы армейские подразделения Абхазии и России, а также сотрудники Министерства внутренних дел и спецслужб Республики Абхазия.

В мае 2009 года президент Республики Абхазия Сергей Багапш сообщил, что численность российских пограничников в Абхазии составит около 
1340 человек, абхазских - около 220 человек. На пограничных переходах (пунктах пропусках) российские пограничники несут службу совместно с абхазскими, в том числе на пунктах пропуска «Ингур» (мост через реку Ингури на абхазско-грузинской границе) и «Сухум» (в аэропорту и морском порту). Таможенный контроль осуществляется исключительно силами Республики Абхазии.

Соглашение с Россией о совместных усилиях в охране государственной границы Абхазии предусматривает и помощь в охране морских границ Абхазии (контроль морской границы Абхазии осуществляется пятью пограничными заставами: в селе Скурча Очамчирского района, в посёлке Мачара Гулрыпшского района, в городе Новый Афон (Гудаутский район), посёлках Пицунда и Цандрыпш (Гантиади) (Гагрский район)). В обеспечении безопасности морской акватории Абхазии принимают участие корабли и катера Черноморско-Азовского пограничного управления береговой охраны Федеральной службы безопасности Российской Федерации.

Пограничное управление Федеральной службы безопасности Российской Федерации в Республике Абхазия осуществляет охрану границы исключительно по законодательству Республики Абхазия, которое в большей части создано на основе законодательства Российской Федерации.

Практически однотипную ситуацию можно встретить и в Республике Южная Осетия. Как уже было ранее отмечено, схожее соглашение заключено и с Южной Осетией, в соответствии с которым с 30 апреля 2009 года Россией и Южной Осетией осуществляется совместная охрана границы с Грузией Пограничным управлением Федеральной службы безопасности Российской Федерации и Пограничной службой Комитета государственной безопасности Республики Южная Осетия. Указанное соглашение ратифицировано Российской Федерацией, а также принят специальный Федеральный закон от 5 апреля 2010 г. № 59-Ф3 «0 ратификации Соглашения между Российской Федерацией и Республикой Южная Осетия о совместных усилиях в охране государственной границы Республики Южная Осетия» [2]. Данное соглашение конкретизируется распоряжением ФСБ России «0 подписании соглашения между Российской Федерацией и Республикой Южная Осетия о совместных усилиях по охране государственной границы республики Южная Осетия», в котором также указано об использовании в работе исключительно национального законодательства (уголовного и административного) Южной Осетии, близкого по содержанию к законодательству Российской Федерации.

Законом Республики Южная Осетия «О государственной границе Республики Южная Осетия» устанавливаются режим государственной границы и пограничный режим, которые включают в себя определённые правила поведения для лиц, пересекающих границы, а также лиц, находящихся на прилегающих к границе территориях. В частности, в данном законе указывается, что выявлением соблюдения выполнения различными лицами предусмотренных правил осуществляют сотрудники Пограничного управления Федеральной службы безопасности Российской Федерации в Республике Южная Осетия, а также Пограничная служба Комитета государственной безопасности Республики Южная Осетия. В период несения службы пограничники наделяются правом производить административное задержание лиц, которыми нарушается режим государственной границы либо пограничный режим. Решение о привлечении задержанных лиц к ответственности принимает судебный орган Республики Южная Осетия. Кроме того, законодательство Южной Осетии устанавливает, что «задержанные лица могут привлекаться к административной и уголовной ответственности в соответствии с Кодексом РФ об административных правонарушениях (применительно к Республике Южная Осетия) (ст. 18.1, ст. 18.2) [3].

Подводя промежуточный итог, стоит отметить, что не существует единого подхода к правовому регулированию деятельности пограничных подразделений Федеральной службы безопасности Российской Федерации по защите границ иностранных государств, в том числе и механизма привлечения ими лиц к административной ответственности за нарушение законодательства, регулирующего порядок пересечения государственной границы этих стран. Так, например, определено, что деятельность пограничных подразделений Федеральной службы безопасности Российской Федерации регулируется национальным законодательством Армении, Абхазии и Южной Осетии, которое в отдельных странах до сих пор или не принято или полностью дублирует законодательство Российской Федерации в части непосредственной деятельности по защите государственной границы, а хозяйственная деятельность указанных органов определяется законодательством Российской Федерации (государственные закупки осуществляются в соответствии с законодательством Российской Федерации, а юридическим адресом таких подразделений согласно официального сайта www.zakupki.gov.ru выступают адреса воинских частей в г. Москве). Не отрегулированы и основания нахождения российских пограничников в иностранных государствах, которые пересекают границу на основании заграничных паспортов на общих основаниях.

Стоит также отметить, что в других странах бывшего СССР ситуация с охраной государствен- 


\section{Административное и муниципальное право 5 (101) • 2016}

ной границы складывалась также по-разному. Где-то российские пограничники продолжали осуществлять свою деятельность после распада СССР, а где-то фактически сразу эти полномочия перешли национальным пограничным органам, фактически без переходного периода. Так, например, в Республике Казахстан также был заключен договор между Российской Федерацией и Республикой Казахстан о совместных усилиях по охране границ и сформирована оперативная группа Пограничных войск Российской Федерации в Республике Казахстан. Однако указанная группа фактически границу не охраняла и в итоге была упразднена. По-сути данная группа была сформирована из остатков советских пограничных войск, которых невозможно было вывести на территорию Российской Федерации или другие страны бывшего СССР. Как правило, личный состав пограничных войск должен был выбрать гражданство и определиться с дальнейшим местом жительства. В настоящее время в Республике Казахстан даже нет российских пограничных советников.

Схожая ситуация была и в Республике Беларусь, где приказом директора Федеральной пограничной службы Российской Федерации и в соответствии с Договором между Российской Федерацией и Республикой Беларусь о совместных усилиях в охране Государственной границы Республики Беларусь сформирована Оперативная группа Пограничных войск Российской Федерации при Главном управлении Пограничных войск Республики Беларусь [4]. По факту, в Республике Беларусь практически сразу после распада СССР стали охранять свою границу самостоятельно. Советников также в настоящее время там нет.

Что касается прибалтийских государств, то 18 марта 1992 г. Президент Российской Федерации издал Указ о переходе Прибалтийского пограничного округа под юрисдикцию России. В последующем уполномоченным Российской Федерации по вопросам временного пребывания и вывода пограничных войск с территории государств Балтии командующим Прибалтийским пограничным округом генерал-лейтенантом В. Гапоненко были подписаны необходимые протоколы о взаимодействии в охране границы и разграничении полномочий.

18 июля 1992 г. Президентом Российской Федерации был подписан Указ «0 неотложных мерах по организации таможенного контроля в Российской Федерации», который имел своим направлением нормализацию таможенной обстановки на границах со странами Балтии. В данном Указе была установлена новая таможенная граница, а 4 ноября 1992 г. Постановлением Верховного Совета Российской Федерации границе России с Латвией,
Литвой и Эстонией был придан статус государственной. Ранее, летом 1992 г., офицерами управления войск Северо-Западного пограничного округа проводилась рекогносцировка мест дислокации частей и подразделений создаваемой в его составе оперативной пограничной группы «Псков». В итоге 15 июля на всех автодорожных пунктах пропуска выставлялись пограничные наряды. Их основная задача состояла в пресечении вывоза сырья и материальных ценностей из России. Ситуация в сфере контроля государственной границы с западными странами осложнялась тем, что в 90-е гг. XX века торговые отношения с иностранными государствами были в значительной степени криминализированы. Так, пограничники и их семьи неоднократно подвергались давлению со стороны преступных групп Санкт-Петербурга и Пскова, вывозивших за границу цветные металлы и другие материальные ценности.

Рассматривая Калининградскую область, отметим, что 2 сентября 1992 г. Президентом Российской Федерации был подписан указ «Об образовании в составе Пограничных войск Российской Федерации Краснознаменной Калининградской группы пограничных войск и об упразднении Краснознаменного Прибалтийского пограничного округа». Группа имела своим предназначением охрану сухопутных и морских границ с Польшей и странами Балтии. В связи с расширением границы был создан ещё один пограничный отряд - Черняховский, укомплектованный на базе бывшего Клайпедского пограничного отряда.

Взаимоотношения с южными соседями Российской Федерации имели также свои особенности. Так, в Грузии события с дислокацией пограничных войск была иная, так как осложнялась внутренним военным конфликтом. Изначально власти Грузии не делали официальных заявлений с требованием вывести российские пограничные войска, однако Грузия практически с самого начала своей независимости приступила к формированию структуры собственных пограничных войск. Так, был принят закон о государственной границе и согласована эта проблема на высшем уровне с Турцией, но принимать под охрану участки самой границы Грузия не спешила. Грузия пыталась использовать присутствие российских пограничных войск, как фактор в грузино-абхазском конфликте. Как грузины, так и абхазцы, поочередно обвиняли российских пограничников «в пособничестве противнику», одновременно пытались втянуть их в конфликт на своей стороне, а поскольку сделать это не удавалось, следовали все новые и новые обвинения. Постоянно подвергавшиеся провокациям российские пограничники оказались фактически заблокированными на территории иностранно- 
го государства, но продолжали выполнять задачи по охране границы, не вмешиваясь во внутренние дела Грузии. Окончательная передача границы с Турцией пограничникам Грузии произошла в 1998-1999 гг., а в октябре 1999 г. полностью завершён вывод с территории Грузии российских пограничных частей и подразделений.

Внутренний военный конфликт в начале 90-х гг. XX века был и в Азербайджане. Так, в июле 1992 г. накалилась обстановка в Нахичеванской Автономной Республике Азербайджана. Руководство Верховного меджлиса Нахичевани обратилось к начальнику российского пограничного отряда полковнику В. Жукову с требованием передать местному руководству пять пограничных застав Ордубадского направления. В тот период времени управление пограничного отряда было фактически изолировано от внешнего мира, прекратились поставки имущества, продовольствия и топлива. К тому времени Соглашение между Россией и Азербайджаном о разделе пограничных войск ещё отсутствовало, но уже появилось решение последнего о взятии под свою юрисдикцию участок границы с Ираном. Меджлис Нахичеванской Республики приступил к его практическому осуществлению. Начался вывод российских пограничников с территории Азербайджана. С сентября 1992 г. по январь 1993 г. пограничные части и подразделения были выведены с территории Азербайджана на территорию России. Первые два отряда были передислоцированы в Дагестан - под Махачкалу и Дербент. К маю 1993 г. еще два отряда встали на охрану побережья Каспия, организовали таможенный контроль на путях из Закавказья в Россию. Фактически в начале-середине 90-х гг. ХХ века сложилась такая ситуация: граница на севере Азербайджана фактически никем не охранялась, и это привело к тому, что на юге Дагестана у России появилась «прозрачная» граница, а это существенно осложняло ситуацию в Чечне, где в 90-е гг. XX века шли боевые действия.

Несомненный интерес для исследования представляют территории иностранных государств, используемые для проживания и осуществления хозяйственной деятельности гражданами Российской Федерации на договорной основе. К таким территориям можно отнести особую территорию Республики Казахстан «Байконур» (космодром и г. Байконур (до декабря 1995 назывался Ле́нинск, который в СССР имел статус закрытого города). Географические координаты космодрома $-46^{\circ}$ ceверной широты и $63^{\circ}$ восточной долготы. Он занимает территорию общей площадью 6717 кв. км.), арендованную Российской Федерацией.

В соответствии с Договором аренды комплекса «Байконур» между Российской Федерацией и Республикой Казахстан комплекс «Байконур» (космодром и г. Байконур) был арендован Российской Федерацией на 20 лет. В целях обеспечения длительной перспективы эффективного использования космодрома Байконур по выполнению различных космических программ Президентами Российской Федерации и Республики Казахстан в январе 2004 года подписано Соглашение, продлевающее срок аренды до 2050 года (до 1994 года космодром Байконур полностью находился в ведении Министерства обороны Российской Федерации. Начиная с 1994 года, активное участие в обеспечение функционирования инфраструктуры космодрома и эксплуатации его объектов, а с октября 1998 г. - в непосредственной подготовке и осуществлении запусков космических аппаратов, принимает Федеральное космическое агентство).

Данная территория вызывает особый интерес с точки зрения защиты контроля её границ, так как это территория иностранного государства, но арендованная Российской Федерации. Возникает вопрос о действии норм российского законодательства на указанной территории, в том числе о привлечении к административной ответственности. Так, стоит отметить, что на Байконуре действуют российские органы исполнительной власти, прокуратура, следственный комитет, судебные органы и другие.

Что касается охраны территории г. Байконур, то на практике существует противоречивая ситуация. Так, в соответствии с пункт 1 статьи 1 Международного соглашения между Российской Федерацией и Республикой Казахстан о статусе города Байконур, порядке формирования и статусе его органов исполнительной власти от 23 декабря 1995 года в городе действует пропускной режим. Однако пограничный контроль в г. Байконуре находится под юрисдикцией Казахстана (в аэропортах Байконура действует пограничный пост «Байконыр»). Таможенный контроль осуществляют также казахские таможенные органы. При выявлении нарушений в сфере пересечения государственной границы также применяется законодательство Республики Казахстан.

Еще одной территорией, представляющей интерес для данного исследования, является остров Шпицберген, который также является особой территорий, но находящейся под юрисдикцией Норвегии в соответствии со Шпицбергенским трактатом, подписанном 17 июня 1925 года.

На Шпицбергене два официальных языка норвежский и русский, для посещения архипелага гражданам России не нужна виза. Что касается въезда на архипелаг, то здесь есть нюансы. Шпицберген как особая территория Норвегии находится вне шенгенской зоны, а также вне Европейского экономического пространства, из-за чего прямо 


\section{Административное и муниципальное право 5 (101) • 2016}

в Лонгйирбюэне функционирует магазин дьютифри. Соответственно, теоретически гражданам России для въезда на архипелаг виза не нужна. Однако фактически туда можно попасть только из континентальной Норвегии (самолёты ежедневно летают из Осло, иногда совершая посадку в Тромсё), а покидая Норвегию гражданам России проставляют «выездной» шенгенский штамп. Следовательно, шенгенская виза всё-таки требуется, причём как минимум двукратная, чтобы можно было вернуться назад. Правда, есть возможность получить визу и на самом архипелаге (там есть норвежские органы власти), да и континентальные посольства и консульства при предъявлении билетов до Шпицбергена ставят визу для транзита быстро и бесплатно.

Что касается граждан Российской Федерации, летающих прямыми рейсами, то, чтобы лететь таким рейсом визы не требуется, так как в аэропорту Лонгйирбюэна нет пограничного контроля, однако требуется заграничный паспорт, так как это международный рейс, и документы должны быть международного образца. При вылете в России проставляется «выездной» российский штамп. Проблемная ситуация возникла с прилётом в 2015 г. на о. Шпицберген вице-премьера Российской Федерации Д. Рогозина, который был внесён в список лиц, на которых распространяются санкции Европейского союза и которым запрещён въезд в страны Европейского союза. В связи с чем, МИД Норвегии выступил с официальным обращением [5]. По мнению автора, такие действия Норвегии прямо нарушают Шпицбергенский трактат, который не обязывает ни одну из стран-участниц договора уведомлять Норвегию о поездках своих граждан на архипелаг.

В сентябре 2000 г. между Норвегией и Россией был подписан договор, определяющий границы между архипелагами Шпицберген и Новая Земля (Земля Франца Иосифа). Поэтому фактически пограничная служба Федеральной службы безопасности Российской Федерации находится на архипелаге Земля Франца Иосифа (пограничная застава «Нагурское» Пограничного управления Федеральной службы безопасности Российской Федерации по Архангельской области), а побережье Шпицбергена охраняют норвежские пограничники.

Итак, подводя итого, можно определить следующие особенности в организации и осуществлении деятельности пограничными органами Федеральной службы безопасности Российской Федерации в области защиты границ иностранных государств. Во-первых, на постсоветском пространстве сложилась разнородная ситуация в сфере охраны Государственных границ Российской Федерации. Во-вторых, приоритет в защите государственных границ бывшего СССР отводился именно внешним границам стран СНГ, за исключением прибалтийских стран, которые начали в первую очередь оборудовать границу с Российской Федерацией. Именно необходимостью защиты внешних границ стран СНГ, а также невозможностью выполнения этой функции самостоятельно в 90-е гг. XX века, объясняется присутствие в иностранных государствах российских пограничных войск. Однако, подобная ситуация встречается не во всех государствах. Так, в Республике Беларусь и Республике Казахстан, практические с первых дней своей независимости начали самостоятельно осуществлять защиту своих государственных границ.

В таких государствах, как Грузия, Армения, Абхазия и Южная Осетия присутствие российских пограничных войск на различных этапах, а также в настоящее время связано в определенной степени с военными конфликтами, происходившими в разные периоды времени в указанных государствах.

В отношении выполнения сотрудниками пограничных подразделений Федеральной службы безопасности Российской Федерации в иностранных государствах полномочий в сфере защиты государственных границ, то данная деятельность регулируется, как правило, национальным законодательством этих государств, что вызывает ряд правовых проблем. Усложняется эта ситуация еще и тем, что значительная часть полномочий российских пограничников вообще не урегулирована ни национальным законодательством, ни международными договорами. В Абхазии и Южной Осетии вообще законодательно определена возможность применения, в связи с отсутствием собственного законодательства, нормативных правовых актов Российской Федерации в области защиты государственных границ. В связи с чем, фактически установлена возможность действия российского, в том числе административного законодательства за пределами Российской Федерации.

\section{Библиография:}

1. Договор между Правительством Российской Федерации и Правительством Республики Армения о статусе Пограничных войск Российской Федерации, находящихся на территории Республики Армения, и условиях их функционирования (Протокол подписан в г. Москве 25.01.1994) // Бюллетень международных договоров.-N 6. - 1995.

2. Федеральный закон от 05.04.2010 N 54-Ф3 "О ратификации Соглашения между Российской Федерацией и Республикой Абхазия о совместных усилиях в охране государственной границы Республики Абхазия" // Российская газета.-2010.-7 апр. 
3. Информационное агентство Республики Южная Осетия (PEC): официальный сайт [Электронный ресурс] URL: http://cominf.org/node/1166493450.-(Дата обращения: 08.03.2016).

4. Договор между Российской Федерацией и Республикой Беларусь о совместных усилиях в охране Государственной границы Республики Беларусь (Подписан в г. Минске 21.02.1995) // СПС «Консультант Плюс».

5. Горина Т. Норвегия возмущена визитом Рогозина на Шпицберген. После этого «инцидента» королевство усилит контроль на границе [Электронный ресурс] // http://www.mk.ru/politics/2015/04/20/norvegiya-trebuetrazyasneniy-po-povodu-vizita-rogozina-na-shpicbergen.html-(дата обращения 20.04.2015).

\section{References (transliterated):}

1. Dogovor mezhdu Pravitel'stvom Rossiiskoi Federatsii i Pravitel'stvom Respubliki Armeniya o statuse Pogranichnykh voisk Rossiiskoi Federatsii, nakhodyashchikhsya na territorii Respubliki Armeniya, i usloviyakh ikh funktsionirovaniya (Protokol podpisan v g. Moskve 25.01.1994) // Byulleten' mezhdunarodnykh dogovorov.-N 6. - 1995.

2. Federal'nyi zakon ot 05.04.2010 N 54-FZ"O ratifikatsii Soglasheniya mezhdu Rossiiskoi Federatsiei i Respublikoi Abkhaziya o sovmestnykh usiliyakh v okhrane gosudarstvennoi granitsy Respubliki Abkhaziya" // Rossiiskaya gazeta.-2010.-7 apr.

3. Informatsionnoe agentstvo Respubliki Yuzhnaya Osetiya (RES): ofitsial'nyi sait [Elektronnyi resurs] URL: http://cominf. org/node/1166493450.-(Data obrashcheniya: 08.03.2016).

4. Dogovor mezhdu Rossiiskoi Federatsiei i Respublikoi Belarus' o sovmestnykh usiliyakh v okhrane Gosudarstvennoi granitsy Respubliki Belarus' (Podpisan v g. Minske 21.02.1995) // SPS «Konsul'tant Plyus».

5. Gorina T. Norvegiya vozmushchena vizitom Rogozina na Shpitsbergen. Posle etogo «intsidenta» korolevstvo usilit kontrol' na granitse [Elektronnyi resurs] // http://www.mk.ru/politics/2015/04/20/norvegiya-trebuet-razyasneniypo-povodu-vizita-rogozina-na-shpicbergen.html-(data obrashcheniya 20.04.2015). 